\title{
繰返し軸荷重を受ける粘土中の杭の安定条件 DESIGN GUIDELINES ON PILES IN CLAY UNDER CYCLIC AXIAL LOADING
}

\author{
稲 国 芳*, 岸田英明** \\ Kuniyoshi INA and Hideaki KISHIDA
}

\begin{abstract}
A stability diagram is proposed for the design of piles in clay under cyclic axial loading. The diagram represents the allowable combination of average load $\left(Q_{\text {ave }}\right)$ and cyclic load amplitude $\left(Q_{\text {amp }}\right)$. The boundary lines between stable and unstable zones are defined by the following relations : (1) $Q_{\max } \leqq Q_{y}$; (2) $2 Q_{\mathrm{amp}} \leqq Q_{y}$; where $Q_{\max }$ is the maximum value of cyclic load (= $Q_{\mathrm{ave}}$ $\left.+Q_{\mathrm{amp}}\right)$ and $Q_{y}$ is yield load obtained by pile load tests. The diagram is compared with the results of field and laboratory tests reported in the literature.
\end{abstract}

Keywords : pile, clay, cyclic load, stability 杭, 粘土, 繰返し荷重, 安定

\section{1.はじめに}

筆者らはこれまでに，一方向の規則的な繰返し軸荷重 （以後，軸荷重は荷重と呼ぶ）を受ける粘土中の杭の変 位応答の解析解 ()を提案し, その妥当性を模型実験”お よび現場実験 ${ }^{2)}$ で検証してきた。その結果によれば，一 方向の規則的な繰返し荷重を受ける粘土中の杭の安定 は，繰返し荷重の最大值を降伏荷重以下に制限すること で確保することができる。しかしながら，杭には，一方 向だけではなく，二方向の繰返し荷重が作用する場合が ある。

Karlsrud ら³ は，粘土地盤中に圧入された鋼管杭に対 して数多くの一方向と二方向の繰返し載荷試験を行って いる。これらの結果は, 一方向の場合に比べて，二方向 の繰返し載荷は杭の支持力に著しい影響を及ぼすことを 示している。一方，Poulos ${ }^{4}$ は，繰返し荷重を受ける 杭の問題を簡易化された境界要素法を用いて解析的に取 扱うことを試みている。また，Malek ら ${ }^{5)}$ は，杭周辺の 土要素のせん断変形モードが単純せん断試験機でシミュ レートできることに着目し，繰返し荷重を受ける杭の挙 動を粘土の繰返し非排水単純せん断試験結果をもとに論 じている。

上述のように，二方向の繰返し荷重を受ける粘土中の 杭に関する既往の研究3) 5)では種々のアプローチが用い られてきたが，その問題が複雑であるため，いずれも実 用的な設計法を提言するまでには至っていないのが現状 である。
本研究は, 一方向の場合に関するこれまでの結果 ${ }^{1,2)}$ をもとに，二方向の絽返し荷重に対する杭の安定条件に ついて考察し，繰返し荷重を受ける粘土中の杭の実用的 な設計指針を提案したものである。ただし，ここでいう 粘土中の杭とは,いわゆる粘土中の摩擦杭のことである。

以下では，まず，一方向と二方向の規則的な繰返し荷 重を受ける粘土中の杭の典型的な挙動について述べる。 次に，既往の粘土の繰返し試験結果を援用することに よって二方向の繰返し荷重に対する杭の安定条件につい て議論し,得られた条件を既往の実験データと比較する。

なお, 本論で提案する安定条件は, 多くの回数に達す る繰返し荷重を受ける杭（たとえば，波浪を受ける海洋 構造物の杭）を念頭において作成されたものである。し たがって，本安定条件は，我が国の主要な検討対象であ る地震時の繰返し荷重を受ける杭に対しては, 概して控 えめである。すなわち, 繰返し回数の比較的少ない地震 時の場合には，この条件を超える繰返し荷重が作用して も，必ずしも杭は破壊に至るとは限らない。しかしなが ら，地震時の場合，に゙の程度までこの条件を楥和できる かの問いに的確に答えることは, 現状では難しい。ゆえ に, 本論で提案する杭の安定条件は，今後のこの種の研 究の進展に応じて緩和されるべき性質を有するものであ る。

\section{2. 典型的な杭の繰返し挙動}

一方向と二方向の繰返し載荷では，粘土中の杭は異
*ジオトップ

** 東京工業大学 教授. 工博
Geotop Corporation

Prof., Tokyo Institute of Technology, Dr. Eng. 
表一1 模型杭の繰返し載荷条件

\begin{tabular}{|c|c|c|c|c|c|c|c|c|c|}
\hline $\begin{array}{c}\text { Test } \\
\text { No. }\end{array}$ & $\begin{array}{c}\text { Cyclic } \\
\text { Test }\end{array}$ & Quva $/ Q_{y}{ }^{*}$ & $Q_{B m p} / Q_{y}{ }^{*}$ & $Q_{\max } / Q_{y}{ }^{*}$ & $Q_{\min } / Q_{y}{ }^{*}$ & $\begin{array}{c}T^{* *} \\
(\mathrm{sec})\end{array}$ & $N^{* * x}$ & Load Shape & Results \\
\hline $\begin{array}{l}1 \\
2\end{array}$ & $\begin{array}{l}\text { One-way } \\
\text { One-way }\end{array}$ & $\begin{array}{l}0.84 \\
0.69\end{array}$ & $\begin{array}{l}0.25 \\
0.25\end{array}$ & $\begin{array}{l}1.09 \\
0.94\end{array}$ & $\begin{array}{l}0.59 \\
0.44\end{array}$ & $\begin{array}{l}28.6 \\
28.6\end{array}$ & $\begin{array}{r}70 \\
2059\end{array}$ & $\begin{array}{l}\text { Triangular } \\
\text { Triangular }\end{array}$ & $\begin{array}{l}\text { Failure } \\
\text { No Failure }\end{array}$ \\
\hline $\begin{array}{l}3 \\
4\end{array}$ & $\begin{array}{l}\text { Tro-may } \\
\text { Two-may }\end{array}$ & $\begin{array}{l}0.06 \\
0.06\end{array}$ & $\begin{array}{l}0.89 \\
0.48\end{array}$ & $\begin{array}{l}0.95 \\
0.54\end{array}$ & $\begin{array}{l}-0.83 \\
-0.42\end{array}$ & $\begin{array}{l}25.2 \\
25.2\end{array}$ & $\begin{array}{r}30 \\
500\end{array}$ & $\left|\begin{array}{l}\text { Sinusoi idal } \\
\text { Si nusoidal }\end{array}\right|$ & $\begin{array}{l}\text { Failure } \\
\text { No Failure }\end{array}$ \\
\hline \multicolumn{10}{|c|}{ * Yield Load } \\
\hline
\end{tabular}

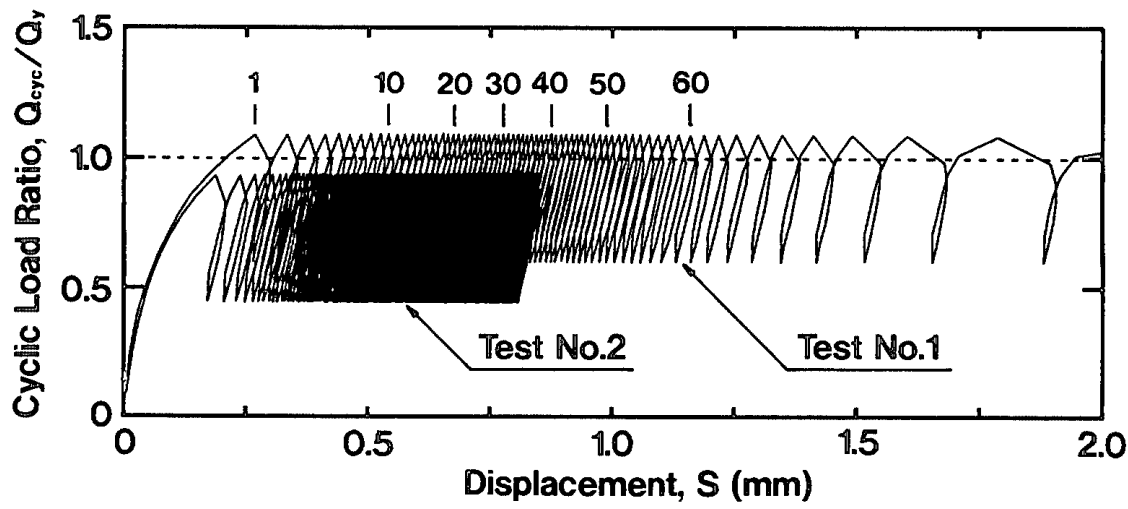

图一1一方向の規則的な繰返し荷重を受ける杭の荷重～変位曲線（試験 No.1 と No. 2)

なった応答を示すことが知られている゙๋。本章ではこ の違いを調べるために実施した模型実験（表一1）の典 型的な結果について述べる。なお, 模型杭の杭径は19 $\mathrm{mm}$ である。実験手順等の詳細については前報”を参照 されたい。

杭に作用する繰返し荷重 $\left(Q_{\mathrm{cyc}}\right)$ は, 波形を正弦波と仮 定すると, 時間 $(t)$ の関数として以下のように表せる。

$$
Q_{\mathrm{cyc}}=Q_{\mathrm{ave}}+Q_{\mathrm{amp}} \cdot \sin (2 \pi t / T)
$$

ここに, $Q_{\text {ave }}$ は平均荷重, $Q_{\mathrm{amp}}$ は荷重振幅, $T$ は周期 である。式（1）は， $Q_{\mathrm{ave}} \geqq Q_{\mathrm{amp}}$ の場合には一方向の 繰返し荷重を， $Q_{\mathrm{ave}}<Q_{\mathrm{amp}}$ の場合には二方向の繰返し 荷重を表す。また, 繰返し荷重の最大值 $\left(Q_{\max }\right)$ と最小 値 $\left(Q_{\min }\right)$ は，以下のようになる。

$$
\begin{aligned}
& Q_{\max }=Q_{\mathrm{ave}}+Q_{\mathrm{amp}} \\
& Q_{\min }=Q_{\mathrm{ave}}-Q_{\mathrm{amp}}
\end{aligned}
$$

したがって, 表一1の繰返し載荷条件は, これらの荷重 項で表してある。さらに, 一方向 (試験 No.1と No.2) と二方向（試験 No. 3 とNo.4）の繰返し載荷における 地盤強度（地盤作製時の圧密圧力）は異なるので，それ ぞれの荷重項は静的載荷で得られた杭の降伏荷重 $\left(Q_{y}\right)$ で正規化してある。ここでいう静的載荷とは，杭に段階 的に荷重を作用させ，その荷重増分および荷重保持時間 をすべて一定とする試験のことである。なお，言うまで もなく, 降状荷重の值には, 杭材の特性, 杭の設置方法 および杭を支える地盤の特性がすべて反映される。

\section{1 一方向の繰返し載荷}

図一1 は, 一方向の繰返し載荷（試験 No.1 と No.2）
における杭の荷重～変位曲線である。繰返し荷重は降伏 荷重で正規化してあり，試験 No.1に示した数字は繰返 し回数を意味している。いずれも，荷重振幅，周期およ び荷重波形は同一であり，平均荷重の大きさだけが異 なっている。試験 No.1 の杭では, 荷重一変位曲線は繰 返し回数が 30 40 回付近までは収束の気配を示したも のの発散に転じ，70回の繰返しで破壊している。一方， 試験 No. 2 の杭では, 荷重〜変位曲線は収束し続け, 2 059 回の繰返し（時間に換算して約 16時間）においても 破壊の兆候は見られない。

図一2 は, 試験 No. 1 とNo. 2 における杭の変位一時 間曲線である。繰返し変位両振幅の大きさは, 破壊間際 の不安定な部分を除き，いずれも繰返し載荷中常に一定

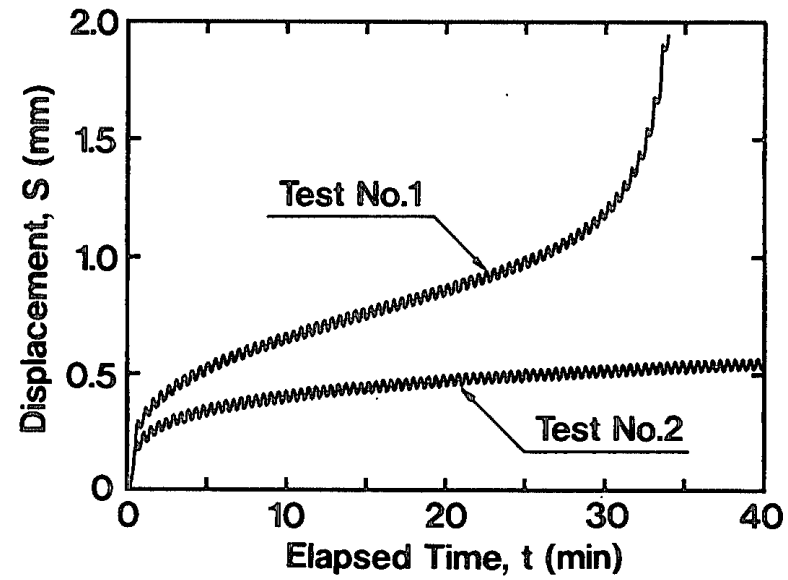

図一2 一方向の規則的な繰返し荷重を受ける杭の変位一時間曲 線（試験 No. 1 と No.2） 


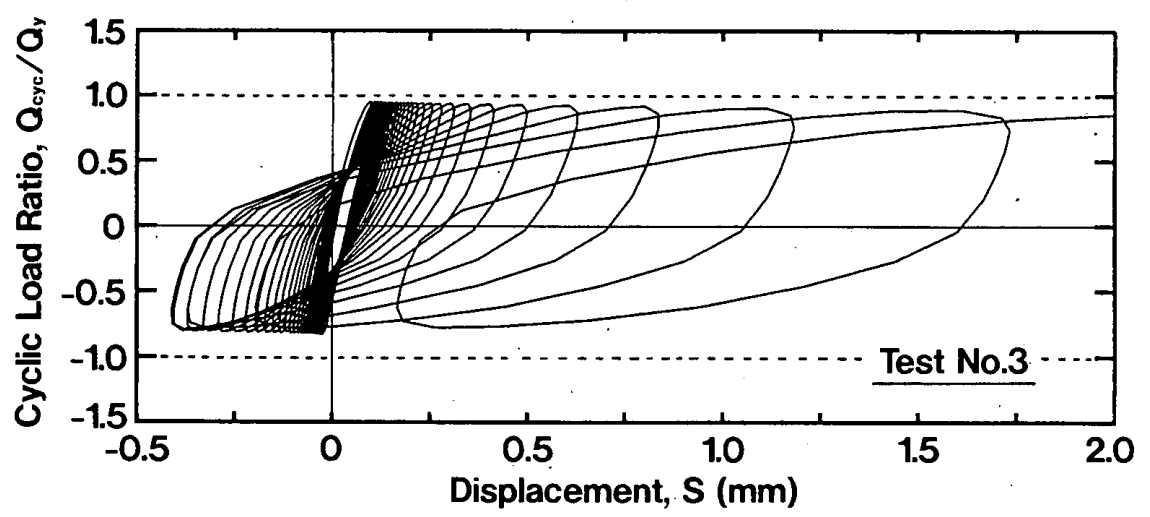

图一3 二方向の規則的な繰返し荷重を受ける杭の荷重－変位曲線（試験 No.3）

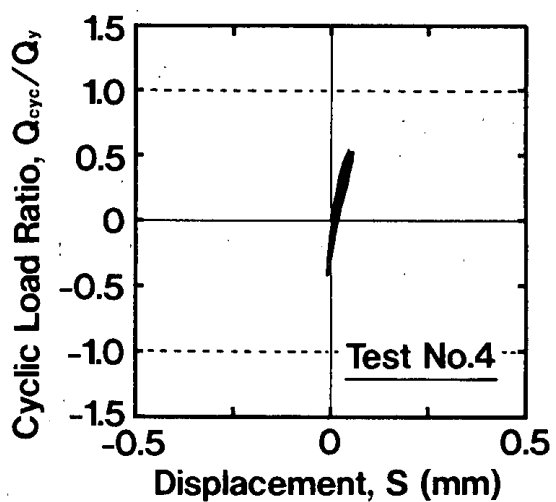

㘡一4 二方向の規則的な繰返し荷重を受ける杭の荷重〜変位曲 線（試験 No.4）

である。また，両者の繰返し変位両振幅の大きさは, 荷 重振幅（ $Q_{\mathrm{amp}} / Q_{y}=0.25 ）$ の大きさが同じであるので, 等しいことがわかる。上述のように, 変位両振幅の大き さは繰返し載荷中常に一定なので，図一2より，一方向 の規則的な繰返し荷重を受ける粘土中の杭が破壊に至る 場合には，累積変位の成長による破壊モードとなること がわかる。

なお，一方向の規則的な繰返し荷重を受ける粘土中の 杭のこのような変位応答は, 筆者ら ${ }^{2)}$ や他の研究者 ${ }^{3), 6), 7)}$ による現場実験でも確認されている。

\section{2 二方向の繰返し載荷}

図一-3〜 4, 二方向の繰返し載荷（試験 No. 3 と No.4）における杭の荷重一変位曲線である。繰返し荷 重は, 一方向の場合と同様, 降伏荷重で正規化してある。 いずれも, 平均荷重, 周期および荷重波形は同一であり, 荷重振幅の大きさだけが異なっている。試験 No. 3 の杭 は30回の繰返し載荷で破壊しているものの, 試験 No. 4 における杭の荷重一変位曲線はほとんど変化して いない。

図一 5 は, 試験 No. 3 と No. 4 における杭の変位一時 間曲線である。同図より, 試験 No. 3 の杭は, 変位両振 幅の大きさが繰返し回数とともに成長することによって 安定性を失い,最終的に破壊に至っていることがわかる。

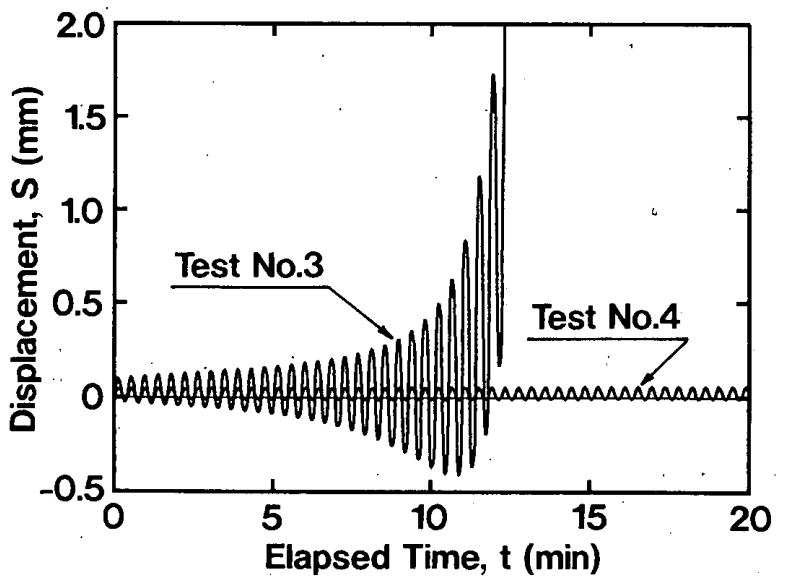

图一5 二方向の規則的な繰返し荷重を受ける杭の变位〜時間曲 線（試験 No. 3 と No. 4)

一方，試験 No. 4 の杭では，500 回の繰返し載荷（時間 に換算して 3.5 時間）においても変位両振幅の大きさは ほとんど変わらなかったので，途中で載荷を中止した。 いずれも平均荷重の大きさがほぼゼロであるので，一方 向の繰返し載荷の場合と対照的に, 累積変位はほとんど 生じていない。

なお，二方向の規則的な繰返し荷重を受ける粘土中の

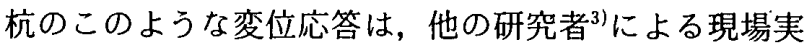
験でも確認されている。

\section{3. 繰返し荷重を受ける杭の安定条件}

\section{1 一方向の繰返し荷重を受ける杭の安定図}

筆者らのこれまでの研究結果 ${ }^{1)}{ }^{21}$ によれば,一方向の 繰返し荷重を受ける粘土中の杭の安定を確保するには, 図一1 からわかるように, 繰返し荷重の最大値を降伏荷 重以下に制限すればよい。このことを繰返し荷重を受け る杭の安定図 ${ }^{37}$,4)上で表すと，図一6のようになる。繰 返し荷重を受ける杭の安定図とは，杭に許容できる繰返 し荷重の平均值 $\left(Q_{\mathrm{ave}}\right)$ と振幅 $\left(Q_{\mathrm{amp}}\right)$ の相互関係を表し たものである。

繰返し荷重の最大值 $\left(Q_{\max }\right)$ が降伏荷重 $\left(Q_{y}\right)$ 以下であ るための条件は, 式 (2) を用いると，以下のように表 せる。 


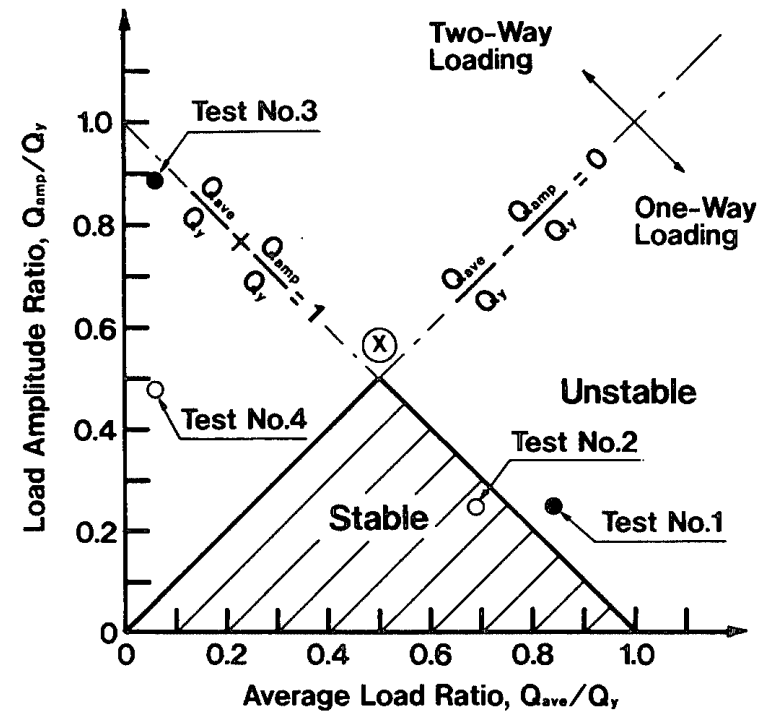

図一6一方向の繰返し荷重を受ける粘土中の杭の安定図

$$
\frac{Q_{\text {ave }}}{Q_{y}}+\frac{Q_{\text {amp }}}{Q_{y}} \leqq 1
$$

また,一方向の繰返し荷重という条件 $\left(Q_{\mathrm{ave}} \geqq Q_{\mathrm{amp}}\right)$ より， 以下の関係式が得られる。

$$
\frac{Q_{\text {ave }}}{Q_{\mathbf{y}}}-\frac{Q_{\text {amp }}}{Q_{\mathbf{y}}} \geqq 0
$$

したがって，粘土中の杭に対する一方向の繰返し荷重の 許容範囲として, 式 (4) と式 (5) より, 図一6 のハッ チ部分が得られる。

図一6の 4 つの丸印は, 第 2 章で述べた模型実験の繰 返し荷重条件（表一1）をプロットしたものである。 印は杭が破壊に至ったことを，○印は破壊には至らな かったことを意味する。試験 No. 3（図一-3）の杭は, 上述の式 (4) の条件 $\left(Q_{\max } \leqq Q_{y}\right)$ を満足するにもかか わらず，わずか 30 回の綝返しで破壊している。一方, 試験 No. 3 とほぼ同じ大きさの最大荷重比 $\left(Q_{\max } / Q_{y}\right)$ で ある試験 No.2（図一1）の杭では, 2000 回以上の繰返 しにおいても破壊の兆候は見られない。このことは，二 方向の繰返し荷重を受ける粘土中の杭には, 一方向の場 合とは別の安定条件を設定することが必要であることを 示している。本章の以下では, この条件について考察す る。

\section{2 二方向の繰返し荷重を受ける杭の安定条件}

第 2 章で述べたように，粘土中の杭は一方向と二方向 の繰返し載荷では異なった応答を示すので，一方向の場 合の安定条件を単純に適用するだけでは,上述のように， 二方向の場合 (図一3) の杭の破壊挙動をうまく説明す ることはできない。

二方向の絽返し載荷が一方向の場合と本質的に異なる 点は,作用する繰返し荷重の方向が交互に逆転すること， すなわち杭を支える粘土はせん断応力の逆転を経験する ことにある。したがって，二方向の繰返し載荷の場合に
は，土の繰返し特性に及ぼす応力逆転の効果に関する情 報が必要である。しかしながら，応力逆転の効果の重要 性8)は認識されているものの, 応力の逆転によって土の 絽返し強度特性は顕著な影響を受けるという定性的な内 容以上のものは，いまだに明らかにされていない。

従来より杭の分野では，このような土の挙動の複雑さ に起因する困難な問題は，実際に載荷試験を行ってみる ことで見実的な解決がなされてきた。実物実験である杭 の載荷試験は，主にその静的な支持力を求めるため，今 日でもしばしば実施されている。しかしながら，二方向 の綝返し試験には載荷方法や反力の確保等に多大の費用 と労力を必要とするため, 静的な支持力を求める場合と 同じような個々のケースに応じた杭の繰返し試験を行う ことは容易なことではない。

そこで，以下では，杭に加えられた繰返し荷重はそれ を支える土に繰返しせん断力として作用することに着目 し，既往の粘土の繰返し試験結果を援用することによっ て, 二方向の綝返し荷重を受ける粘土中の杭（摩擦杭） の安定条件について検討する。

\section{(1) 前提条件}

検討の前提として，以下の(1)（3)を仮定する。

(1) 粘土中の杭の先端抵抗力は無視し得るほど小さい。

(2) 杭の周面抵抗力はそれを支える粘土のせん断抵抗力 として発揮される。

(3) 粘土中の杭は押込み側と引抜き僋で同じ応答を示 す。すなわち，押込み側と引拢き側では降伏荷重（ある いは極限荷重）の大きさは等しい。

(1)は，杭長が短い場合を除き，実用上許される仮定亡 考えられる。また，杭の表面が極めて滑らかな場合は杭 と粘土の境界面で滑りが発生する9可能性があるが，引 抜かれた杭の全面に粘土が付着していたとの報告 ${ }^{10), 11) を ~}$ 考虑すると，実際の杭では(2)の仮定が満たされると考え られる。さらに，粘性土中の杭に関する最近の実験的研 究 $^{12) 15)}$ は，(3)の仮定がほぼ成立することを示している。 以上により, 通常の粘土中の杭では, 上記の仮定がほぼ 満足されると考えることができる。

\section{（2）繰返し応力を受ける粘土の挙動}

粘土の繰返し試験結果は, 上述の仮定が満足される粘 土中の杭の繰返し挙動を解明するための有用な手段と考 えられる。ここでは, 既往の粘土の繰返し試験結果につ いて述べる。

Sangrey $ら^{16)}$ は, 飽和粘土に対して一連の一方向繰返 し非排水三軸試験を行っている。これらの結果は, 通常 の静的強度以下の応力であっても繰返し作用すると試料 は破壊に至るが，繰返し回数をいくら増やしても破壊に 至ることはない応力の限界值 (Critical Level of Repeated Loading : CLRL) が存在することを示している。 すなわち，この限界值を超えない応カレベルのもとでの 


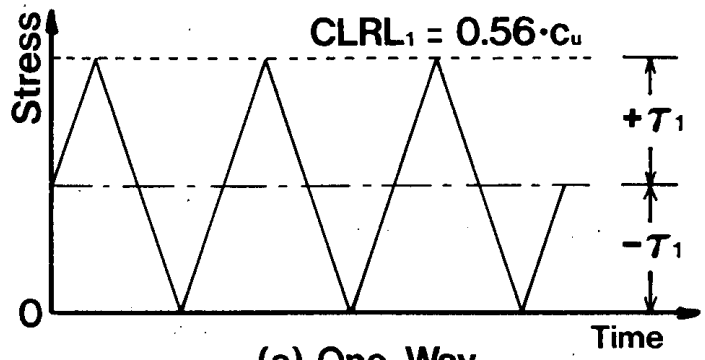

(a) One-Way

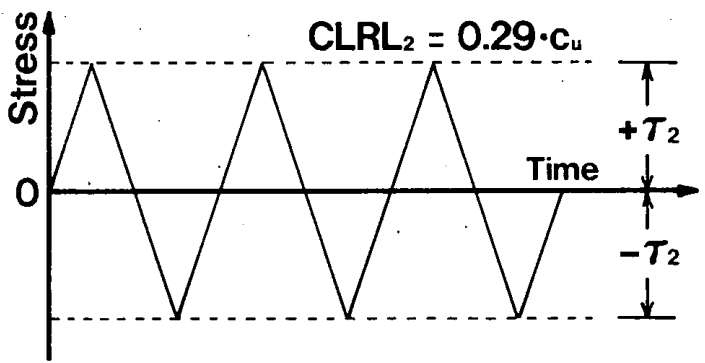

(b) Two-Way

図一7 一方向と二方向の非破壊応力限界值の模式図 (試験結果は, Conn ら ${ }^{24), 25) に よ る) ~}$

繰返しでは，回数を増やしてももはやそれ以上有効応力 および軸ひずみが変化しない平衡状態が現れる。同様の 非破壊応力限界值の存在は, 多くの研究者 ${ }^{17) ~ 21)}$ によっ て報告されている。

二方向の繰返し試験においても,一方向の場合と同様, 粘土には非破壊応力の限界值が存在することが報告され ている。数少ない二方向の例5),221,23) は，主に単純せん断 試験による非排水条件で，初期せん断応力をゼロとする 対称的な繰返しによる試験である。これらの試験結果は いずれも，正規圧密試料の非破壊応力限界值は静的強度 の 4 割程度であることを示している。

一方, Conn ら ${ }^{24), 25)}$ は, 繰返し非排水三軸試験におい て, 一方向と二方向の粘土の非破壊応力限界値を比較し た結果を報告している。一方向の結果は最小応力をゼ口 とした圧縮側への繰返しで得られた值であり，二方向 の結果は初期せん断応力をゼロとした対称的な繰返し で得られた值である。図一7 は正規圧密試料の結果を 模式的に表したものである。ただし，試験結果は静的強 度 $\left(c_{u}\right)$ で正規化してある。同図より，二方向の限界值 $\left(\mathrm{CLRL}_{2}\right)$ は一方向の限界值 $\left(C L R L_{1}\right)$ よりはるかに 小さいことがわかる。しかしながら，一方向の限界値の 応力振幅 $\left(\tau_{1}=0.28 \cdot c_{u}\right)$ 之二方向の限界値の応力振幅 $\left(\tau_{2}\right.$ $\left.=0.29 \cdot c_{u}\right)$ を比較すると, 両者はほぼ同じ値である。 Conn ら ${ }^{24)}$ は，この結果をもとに，応力振幅は土の繰返 し応答を決定する重要な要因であることを示唆してい る。

（3）絽返し荷重を受ける杭の安定図

上述の粘土の繰返し試験結果は，粘土中の杭の安定を
確保するには，繰返し荷重の最大値に対してだけではな く，荷重振幅の大きさに対しても制限を設けることが必 要であることを示している。繰返し荷重の最大值に対す る制限は，式（4）で示したように，一方向の繰返し荷 重を受ける杭の安定に必要である。一方, 荷重振幅の大 きさに対する制限は，前述の図一 3 - 5 の実験結果から もわかるように，二方向の繰返し荷重を受ける杭の安定 にとって重要な条件となる。

言うまでもなく，繰返し荷重を受ける杭の近傍の粘土 の挙動は, 明確な境界条件 (排水条件) のもとで行われ た粘土の繰返し挙動とは異なる可能性がある。しかしな がら，粘土の繰返し試験における一方向と二方向の応力 振幅の関係（図一7）は，同じ境界条件のもとで得られ た結果であるので，粘土中の杭の場合に対しても適用可 能と考えられる。すなわち，二方向の繰返し荷重を受け る粘土中の杭に対する荷重振幅 ( $\left.Q_{\mathrm{amp}}\right)$ の制約条件は, 図一7の実験結果から，以下のように設定することが有 効であることが推定できる。

$$
Q_{\text {amp }} \leqq Q_{\text {amp }}^{*}
$$

ここに， $Q_{a m p}^{*}$ は一方向の場合に許容できる荷重振幅の 最大值である。式（6）の関係を採用すれば，二方向の 繰返し荷重に対する杭の安定条件は，図一6から簡単に 求めることができる。すなわち，一方向の場合に許容で きる荷重振幅の最大值 $\left(Q_{\mathrm{amp}}^{*}\right)$ は, 図一6の囚点の条件か ら，以下のように得られる。

$$
Q_{\mathrm{amp}}^{*}=0.5 \cdot Q_{y}
$$

したがって, 式 (6) と式（7）より，二方向の繰返し 荷重を受ける粘土中の杭に対する荷重振幅 (Qamp) の制 約条件は，以下のようになる。

$$
\frac{Q_{\mathrm{amp}}}{Q_{\mathrm{y}}} \leqq 0.5
$$

なお，二方向の繰返し荷重という条件 $\left(Q_{\mathrm{ave}}<Q_{\mathrm{amp}}\right)$ か

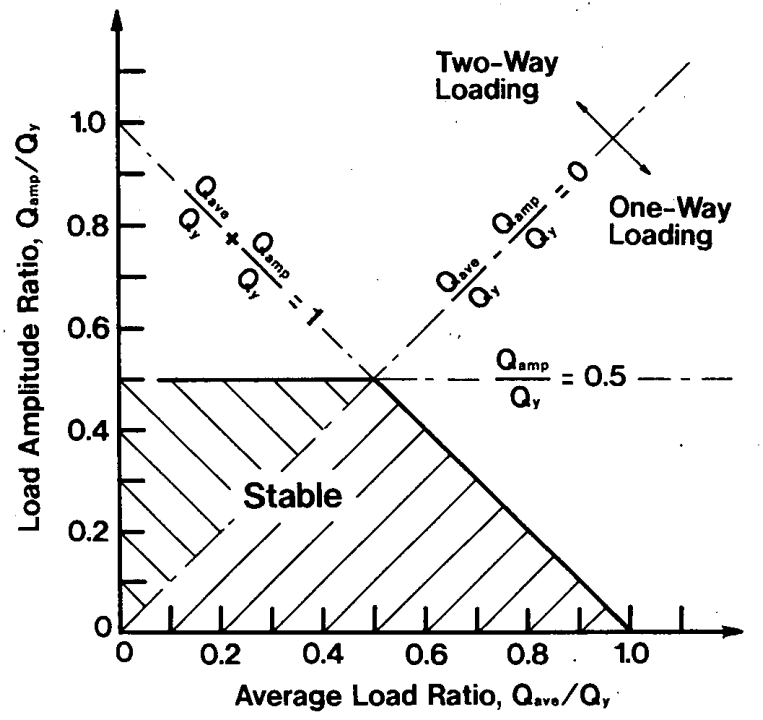

図一8 繰返し荷重を受ける粘土中の杭の安定図 
らは, 以下の関係式が得られる。

$$
\frac{Q_{\text {ave }}}{Q_{y}}-\frac{Q_{\text {amp }}}{Q_{y}}<0
$$

以上により,一方向の場合 (図一6)に式（８) と式（9) の関係を書き加えると, 繰返し荷重を受ける粘土中の杭 の全体の安定荷重領域は，図一8のハッチ部分となる。

\section{4. 既往の実験データとの比較}

本章では, 図一8に示した絽返し荷重を受ける粘土中 の杭の安定条件を既往の実験デー夕と比較し，その妥当 性を検討する。比較のための実験デー夕は，冒頭で述べ

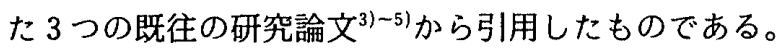

\section{1 単純世ん断式験 ${ }^{5}$}

図一9 は，Malek ら ${ }^{5)}$ の報告による応力制御方式の繰 返し非排水単純せん断試験結果である。試験に用いられ た試料は正規圧密粘土（Boston Blue Clay）である。 試験結果は静的強度 $\left(c_{u}\right)$ で正規化された平均せん断応 力比 $\left(\tau_{\mathrm{ave}} / c_{u}\right)$ と絽返しせん断応力比 $\left(\tau_{c} / c_{u}\right)$ の関係で与 えられている。丸印は $\tau_{\mathrm{ave}} \neq 0$ の繰返しせん断試験を， 四角印は $\tau_{\mathrm{ave}}=0$ の繰返しせん断試験を意味する。なお, これらの応力比と杭の荷重比とは，以下のように対応す ると考えることができる。

$$
\begin{aligned}
& \tau_{\mathrm{ave}} / c_{u} \rightarrow Q_{\mathrm{ave}} / Q_{u} \\
& \tau_{c} / c_{u} \rightarrow Q_{\mathrm{amp}} / Q_{u}
\end{aligned}
$$

ここに, $Q_{u}$ は杭の極限荷重である。

正規化の基準値である静的強度 $\left(c_{u}\right)$ はひずみ制御に よる試験で求められているので, 図一8で必要な杭の降 伏荷重に相当する粘土の降伏応力 $\left(\tau_{y}\right)$ を知ることはでき ない。しかしながら，Malek らうは， $\tau_{\text {ave }}=0$ の二方向 の繰返しせん断試験において，それ以下では粘土が破壊 することはない限界応力として以下の値を提示してい る。

$$
\tau_{c} / c_{u} \doteqdot 0.4
$$

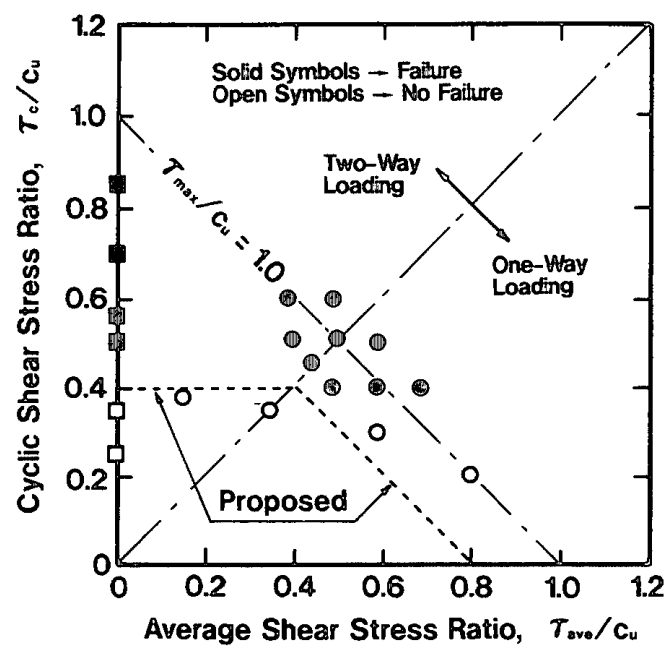

图一9 正規圧密粘土の非排水繰返し単純せん断武験結果 (Malek $ら^{5)}$ によるものに一部加筆)
したがって，図一8および式（10）より，粘土の降伏応 力 $\left(\tau_{y}\right)$ は以下のように推定される。

$$
\tau_{y} / c_{u} \doteqdot 0.8
$$

図一9の点線は, 式 (10) と式（11）によって得られ た粘土の安定応力領域の境界線である。二方向の絽返し せん断領域の結果は, 式（10）の根拠をなすものである ので，良い一致を示すのは当然であるが，一方向の繰返 しせん断領域の結果はうまく対応していない。これは, Malek $ら^{5)}$ が繰返しせん断応力 $\left(\tau_{c}\right)$ を非排水条件で作用 させる前に平均せん断応力 $\left(\tau_{\mathrm{ave}}\right)$ を排水条件で式料に作 用させたため， $\tau_{\text {ave }}$ が大きな試料ほどより大きな強度を 有することによると考えることができる。すなわち,個々 の試料を $\tau_{\mathrm{ave}}$ が作用した後の実際の強度で正規化して やると， $\tau_{\mathrm{ave}}$ が大きな試験結果ほざ図一 9 上で原点に向 かってシフトする量が大きくなる。

以上を考慮すると，図一9 の繰返し単純せん断試験結 果は，本論で提案する安定条件（図一8）によってうま く解釈できるであろうことが推定される。

\subsection{NGI の実験 ${ }^{3}$}

Karlsrud ら ${ }^{3 /}$ は，一様な粘土地盤中に圧入された鋼管 杭（杭径 $15.3 \mathrm{~cm}$, 杭長 $5.15 \mathrm{~m}$, 肉厚 $4.5 \mathrm{~mm}$ ) に対す る一連の繰返し載荷試験結果を報告している。試験は, 規則的な繰返し荷重の平均值 $\left(Q_{\mathrm{ave}}\right)$ と振幅 $\left(Q_{\mathrm{amp}}\right)$ の 種々の組み合わせにより，一方向と二方向の繰返し荷重 領域で行われている。なお,一方向の繰返し荷重領域は, 引抜き側である。

図一10は, 後述の図一11 の結果から, Karlsrud ら3) によって選定された一方向の繰返し載荷試験結果であ る。この結果は $Q_{\min } / Q_{u} \doteqdot 0.05$ のデー夕のみを集めた ものである。なお，図中の丸，三角および四角の記号の 意味は，原論文 ${ }^{3)}$ 中で説明されていないので，不明であ る。同図より，一方向の規則的な繰返し荷重を受ける粘 土中の杭には，それ以下では破壊に至ることはない限界

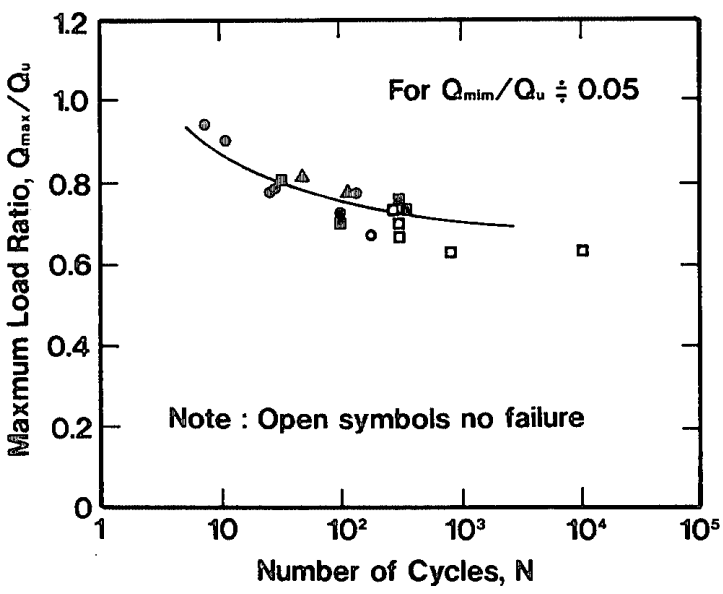

图一10 NGI による杭の一方向繰返し載荷試験結果 (Karlsrud ら゙にによる) 


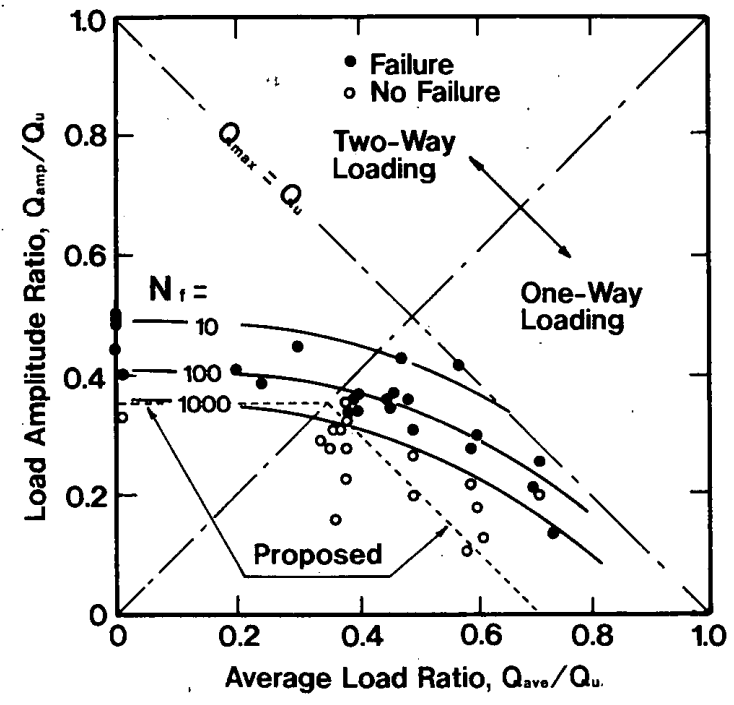

图一11 NGIによる杭の綠返し載荷試験結果

(Karlsrud ら)によるものに一部加筆)

荷重が存在すること，およびその大きさは $Q_{\max } / Q_{u} \doteqdot$ 0.7 であることがわかる。

一方向の規則的な繰返し荷重を受ける粘土中の杭の安 定を確保するには，繰返し荷重の最大值を降伏荷重以下 にすればよいことを述べた。すなわち， $Q_{\max } \leqq Q_{y}$ であ る。したがって，この関係と上述の図一10 の限界荷重 の関係から，この現場における杭の降代荷重 $\left(Q_{y}\right)$ と極 限荷重 $\left(Q_{u}\right)$ の関係が，以下のように推定できる。

$$
Q_{y} \doteqdot 0.7 \cdot Q_{u}
$$

図一11 は，安定図上にプロットされた一方向と二方 向の繰返し載荷試験結果である。ただし, 縦軸 ( $\left.Q_{\mathrm{amp}}\right)$ 之横軸 $\left(Q_{\mathrm{ave}}\right)$ は，本論で用いた杭の降伏荷重 $\left(Q_{\mathrm{y}}\right)$ では なく，極限荷重 $\left(Q_{u}\right)$ で正規化されている。この極限荷 重は，破壊に至るまで約 20 分を要した比較的短い載荷 時間で得られた值である。図一11の3つの曲線は，杭 が破壊に至るまでに要する繰返し回数 $\left(N_{s}\right)$ を表してお り，Karlsrud ら゙にによって書込まれたものである。

一方，図一11の点線は，式（12）の関係をもとに, 杭の安定荷重領域(図一8)の境界線を示したものである。 一方向の繰返し荷重領域の一部で差異が見られるもの の, 安定荷重領域内で破壊に至った杭は皆無である。し たがって, 図一11より, 本論で提案する杭の安定条件は, これらの実験結果と矛盾することはないことがわかる。

\subsection{Poulos $^{4)}$ の収集デー夕}

図一12 は，Poulos")によって収集された繰返し載荷 試験結果である。試験結果は安定図上で提供されており， 図中の記号「F」は繰返し載荷によって杭が破壊に至っ たことを意味している。

繰返し載荷試験結果は種類の異なるすべての杭につい て極限荷重で正規化してあるので，本論の安定図（図一 8）で必要な杭の降伏荷重 $\left(Q_{y}\right)$ を個々に知ることは困難 である。しかしながら，図一12には上述の $\mathrm{NGI}^{3)}$ の実
O Tests with no failure for $N>10,000$

$\triangle F$ Test with failure at $N=564$ McAnoy et aL(1982)

- Tests of Puesch(1982) - no failure

$X$ Stevens(1978) - no settlement

- Stevens(1978) - continuing settlement

$\square$ F Stevens(1978) - plunging fallure

$\checkmark$ F Poulos(1981) - model tests, failure after 3-180 cycles

E Karisrud et al(1986) - faibure after 100 cycles

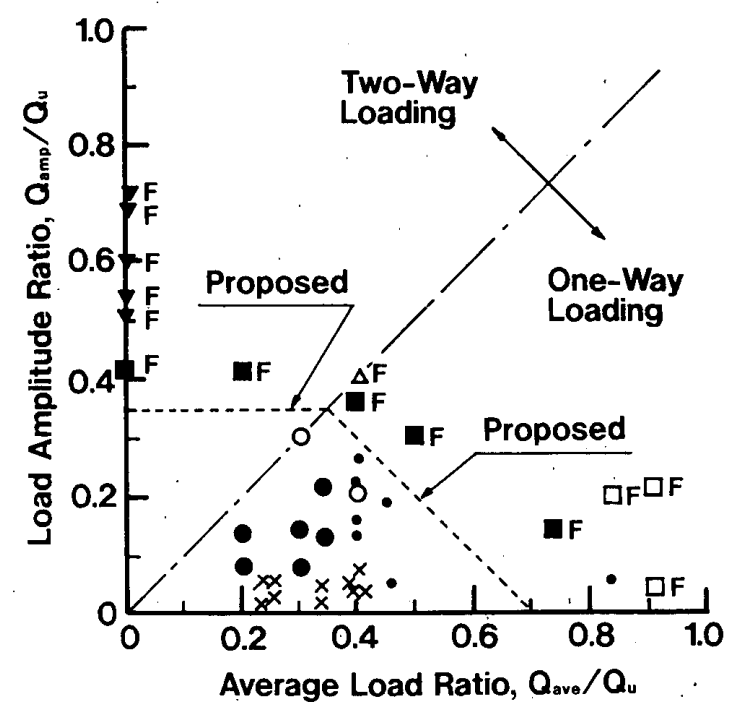

図一12 Poulosによって収集された杭の繰返し載荷試験結果 (Poulos ${ }^{4}$ によるものに一部加筆)

験結果の一部（回印：Poulos') の選択によるもの）が 含まれているので, 式 (12) の関係がこの場合にも適用 できるものとして結果の解积を行う。

図一12 の点線は, 式（12）に従って求めた安定荷重 領域（図一8）の境界線である。同図より，本論で提案 する杭の安定条件によれば, Poulos ${ }^{4)}$ の収集データの 結果をうまく説明できることがわかる。

\section{5. 降伏荷重と極限荷重の関係}

これまでに述べてきたように，本論で提案する杭の安 定条件 (図一8)には, 降伏荷重を知ることが必要である。 静的載荷試験は, 杭の降伏荷重を求めるための最適な手 段であるが，常に実施できるとは限らない。一方，慣用 の支持力計算式 ${ }^{26)}$ を用いれば，地盤調查結果から粘土中 の杭の極限荷重を推定することが可能である。したがっ て, 降伏荷重と極限荷重の関係が与えられれば，本安定 条件の実用性はさらに増すと考えられる。

第 4 章の既往の実験デー夕は, 本安定条件と以下の関 係を用いることでうまく解粕することが可能であった。

$$
Q_{y} / Q_{u} \doteqdot 0.7
$$

そこで, 式（13）の実用的な妥当性を，これまでの筆者 らの実験結果と既往の文献の調査結果をもとに, 以下で 検討する。

表一 2 は，筆者ら ${ }^{1), 2)}$ が行った静的載荷試験結果であ る。同表には，模型実験”（試験 No.S 1 S 3) と現場 
表一2 筆者ら ${ }^{1 /, 2)}$ による静的載荷試験結果

\begin{tabular}{c|c|c|c|c|c|c}
\hline $\begin{array}{c}\text { Test } \\
\text { No. }\end{array}$ & Load Increment & $\begin{array}{c}\text { Time Interval } \\
(\mathrm{sec})\end{array}$ & Load Step & $\begin{array}{c}\text { Ultimate Load } \\
\left(Q_{u}\right)\end{array}$ & $\begin{array}{c}\text { Yield Load } \\
\left(Q_{y}\right)\end{array}$ & $Q_{y} / Q_{u}$ \\
\hline
\end{tabular}

(a) Model Tests ${ }^{11}$

\begin{tabular}{l|l|l|l|l|l|l}
\hline S1 & $2.50(\mathrm{kgf})$ & 90 & 11 & $27.5(\mathrm{kgf})$ & $19.3(\mathrm{kgf})$ & 0.70 \\
S2 & $2.50(\mathrm{kgf})$ & 300 & 10 & $25.0(\mathrm{kgf})$ & $19.0(\mathrm{kgf})$ & 0.76 \\
S3 & $2.00(\mathrm{kgf})$ & 900 & 12 & $24.0(\mathrm{kgf})$ & $18.9(\mathrm{kgf})$ & 0.79 \\
\hline
\end{tabular}

(b) Field Tests ${ }^{2}$

\begin{tabular}{l|l|l|l|l|l|l}
\hline 2 & $1.50(\mathrm{tf})$ & 900 & 12 & $18.0(\mathrm{tf})$ & $14.4(\mathrm{tf})$ & 0.80 \\
6 & $1.50(\mathrm{tf})$ & 900 & 12 & $18.0(\mathrm{tf})$ & $14.6(\mathrm{tf})$ & 0.81 \\
\hline
\end{tabular}

表一3 Fredriksson ら ${ }^{28)}$ による静的載荷試験結果

\begin{tabular}{|c|c|c|c|c|}
\hline $\begin{array}{r}\text { Pile } \\
\text { No. } \\
\end{array}$ & Dimension & $\begin{array}{c}\text { Ultimate Load } \\
Q_{u}(k N)\end{array}$ & $\begin{array}{l}\text { Yield Load } \\
Q_{v}(\mathrm{kN})\end{array}$ & $Q_{y} / Q_{u}$ \\
\hline $\begin{array}{l}\text { B1 } \\
\text { B2 } \\
\text { B3 } \\
\text { B4 } \\
\text { B5 } \\
\text { B6 }\end{array}$ & $\begin{array}{l}18 m \text { mood }+10 \text { m concrete } 0.27 * 0.27 \text { m } \\
32 m \text { concrete } 0.27 * 0.27 m \\
35 \text { m concrete } 0.27 * 0.27 m \\
18 m \text { mood }+10 m \text { concrete } 0.27 * 0.27 m \\
32 m \text { concrete } 0.27 * 0.27 \square \\
35 m \text { concrete } 0.27 * 0.27 \square\end{array}$ & $\begin{array}{l}560 \\
550 \\
670 \\
570 \\
460 \\
630\end{array}$ & $\begin{array}{l}490 \\
480 \\
560 \\
510 \\
390 \\
530\end{array}$ & $\begin{array}{l}0.88 \\
0.87 \\
0.84 \\
0.89 \\
0.85 \\
0.84\end{array}$ \\
\hline & \multicolumn{4}{|c|}{$\begin{array}{l}\text { Load Increment }: 1 / 10 \text { of estimated failure load } \\
\text { Time Interval : } 18 \text { (四) }\end{array}$} \\
\hline
\end{tabular}

実験 ${ }^{2}$ (試験 No.2 と 6) が含まれている。この模型実 験は, 第 2 章における繰返し載荷試験の一部と並行して 行ったものである。3つの模型実験の違いは，載荷速度 （主に荷重保持時間）が異なる点である。このため極限 荷重の值はそれぞれ異なるが，降伏荷重の值はいずれも ほぼ同じである。

筆者らは前報1)で，粘土中の杭の基準值とすべき支持 力は, 載荷速度によってその大きさが変化する極限值で はなく，載荷速度の影響を受けない降伏値を用いるほう が合理的であることを述べた。繰返し荷重を受ける杭の 安定条件(図一8)を降伏荷重で表現する理由のひとつは， このことにある。なお，粘土中の杭の降伏荷重の值が載

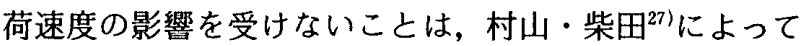
も報告されている。

現場実験（試験No.2 6 6) は, 同一寸法（杭径 $190.7 \mathrm{~mm}$, 杭長 $11.3 \mathrm{~m}$ ) の鋼管杭に対して同じ載荷条 件で行ったものである。すべての条件が同一なので，表 一2より，得られた結果はほとんど同じであることがわ かる。

表一3 は, Fredriksson ら ${ }^{28)} の$ 報告による軟弱な粘土 中の杭の静的載荷試験結果である。試験は 3 種類の杭に 対して合計 6 本行われている。載荷方法は，杭に段階的 に荷重を作用させ，その荷重増分を予想される極限荷重 の $10 \%$, 荷重保持時間を 18 分とする荷重制御方式であ
る。

以上の 3 ケースにおける $Q_{y} / Q_{u}$ の值は，表一 $2 \sim 3$ の 右側の欄に示してある。数は少ないが，これらより，粘 土中の杭の降伏荷重の值は極限荷重の值の 7 割以上で, 9 割近くに達する場合もあることがわかる。

一方, 杉村 ${ }^{29)}$ と茶谷 ${ }^{301}$ は独立して, 数多くの杭の引 拔き載荷試験結果の解析をもとに，平均的な值として以 下の関係を提示している。

$$
Q_{y} / Q_{u} \fallingdotseq 2 / 3
$$

両者のデータには様々な地盤における試験結果が含まれ ているので，粘土中の杭に対して式 (14) が適合すると は一概に言えない。しかしながら，デー夕数の豊富さを 考慮すると, 式 (14) は意義のあるものと考えられる。

以上の結果を総合すると, 繰返し荷重を受ける粘土中 の杭の安定条件を考慮するに際し，式 (13) の関係を用 いることは実用上妥当であると考えられる。

ただし，地盤調査結果から杭の極限荷重を推定する慣 用の支持力計算式 ${ }^{26)}$ は現状では精度が高いとは言えない ので，杭の降伏荷重を求めるには載荷試験を行うことを 原則とすることに変わりはない。

\section{6. 結 論}

本研究の結論は, 以下のように要約される。

(1) 粘土中の杭の安定を確保するために, 作用する繰返 


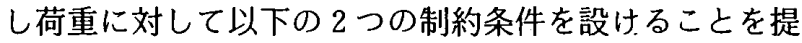
案する(図一8)。

$$
\begin{aligned}
& Q_{\max } \leqq Q_{y} \\
& 2 \cdot Q_{\mathrm{amp}} \leqq Q_{y}
\end{aligned}
$$

(2) 上記の $2 つ の$ 制約条件は，既往の実験データと比較 して，妥当であると考えられる。

(3) $Q_{y}$ を求めるには載荷試験を行うことを原則とする が，やむを得ない場合には，以下の関係を用いることが 可能と考えられる。

$$
Q_{y} / Q_{u} \fallingdotseq 0.7
$$

ここに, $Q_{u} \cdot$ は杭の極限荷重である。

\section{謝 辞}

本論の作成にあたり，研究成果を引用させていただい た多くの著者に心から謝意を表します。また，本研究を まとめるにあたり，千葉大学工学部上杉守道助教授の助 言を受けました。記して謝意を表します。

\section{参考文献}

1）稲 国芳，岸田英明：繰返し軸荷重を受ける粘土中の杭 の変位応答, 日本建築学会構造系論文報告集, 第 435 号, pp. 71 80, 1992

2）稲 国芳, 岸田英明：粘性土中の杭の繰返し引抜き挙動, 日本建築学会構造系論文報告集, 第 438 号, pp. 137 146, 1992

3) Karlsrud, K. et al. : Piles in Clay under Cyclic Axial loading-Field Tests and Computational Modelling, Proc., 3rd International Conference on Numerical Methods in Offshore Piling, pp. 165 190, 1986

4) Poulos, H.G. : Cyclic Stability Diagram for Axially Loaded Piles, Journal of Geotechnical Engineering, ASCE, Vol.114, No. 8, pp. 877 895, 1988

5) Malek, A.M. et al. : Behavior of Foundation Clays Supporting Compliant Offshore Structures, Journal of Geotechnical Engineering, ASCE, Vol.115, No.5, pp. $615 \sim 636,1989$

6) McAnoy, R.P.L. et al. : Cyclic Tensile Testing of a Pile in Glacial Till, Proc., 2nd International Conference on Numerical Methods in Offshore Piling, pp. 257 292, 1982

7) Puech, A.A. : Basic Data for the Design of Tension Piles in Silty Soils, Proc., 3rd International Conference on the Behaviour of Offshore Structures, BOSS'82, Vol. 1, pp. 141 157, 1982

8) Houston, W. N. and Herrmann, H. G. : Undrained Cyclic Strength of Marine Soils, Journal of the Geotechnical Engineering Division, ASCE, Vol.106, No.GT6, pp. $691 \sim 712,1980$

9）内川祐一郎ほか 2 名：単純せん断型試験機による粘土-鋁
材間の摩擦, 第 25 回土質工学研究発表会, 2 分冊の 1 , pp. 707 708, 1990

10) Broms, B. and Hansbo, S. : Soft Clay Engineering, Developments in Geotechnical Engineering 20, Edited by Brand, E. W. and Brenner, R. P., Elsevier Scientific Publishing Company, pp. 417 478, 1981

11) Jaime, A.P. et al. : Static Tests on Friction Piles in Mexico City Clay, Proc., 12th ICSMFE, Vol.2, pp. 1141 1146, 1989

12) Karlsrud, K. and Haugen, T. : Axial Static Capacity of Steel Model Piles in Overconsolidated Clay, Proc., 11th ICSMFE, Vol. 3, pp. 1401 1406, 1985

13）伊藤圭典ほか 3 名：送電用鉄塔基礎杭の引抜き抵抗の評 価法に関する考察，土木学会論文集，第 412 号／III-12, pp. $137 \sim 142,1989$

14）矢島淳二ほか 2 名：鉛直・引抜き交番荷重を受ける杭の 摩擦抵抗, 日本建築学会大会学術講演梗概集 B 構造 I, pp. $1315 \sim 1316,1989$

15) Sugimura, Y. et al. : Cyclic Pull and Load Tests on Cast-in-place Concrete Piles, Proc. of the Ninth Asian Regional Conference on Soil Mechanics and Foundation Engineering, Vol. 1, pp. 293 296, 1991

16) Sangrey, D. A. et al. : The Effective Stress Response of a Saturated Clay Soil to Repeated Loading, Canadian Geotechnical Journal, Vol.6, No. 3, pp. 241 252, 1969

17) Lashine, A.K.F. : Deformation Characteristics of a Silty Clay under Repeated Loading, Proc., 8th ICSMFE, Vol. 1, pp. 237 244, 1973

18) Mitchell, R. J. and King, R. D. : Cyclic Loading of an Ottawa Area Champlain Sea Clay, Canadian Geotechnical Journal, Vol.14, pp. 52 63, 1977

19) Motherwell, J.T. and Wright, S.G. : Ocean Wave Load Effects on Soft Clay Behavior, Proc. of the ASCE Geotechnical Engineering Division Specialty Conference on Earthquake Engineering and Soil Dynamics, Pasadena, Vol. 2, pp. 620 635, 1978

20) Meimon, Y. Hicher, P.Y. : Mechanical Behaviour of Clays under Cyclic Loading, International Symposium on Soils under Cyclic and Transient Loading, Swansea, pp. $77 \sim 87,1980$

21) Lefebvre, G. et al. : Stability threshold for Cyclic Loading of Saturated Clay, Canadian Geotechnical Journal, Vol.26, pp. 122 -131, 1989

22) Andersen, K.H. et al. : Effect of Cyclic Loading on Clay Behaviour, Proc. of the Conference on Design and Construction of Offshore Structures, ICE, pp. 75 79, 1976

23) Dyvik, R. et al. : Cyclic Simple Shear Behavior of Fine Grained Soils, Proc., International Conference on Recent Advances in Geotechnical Earthquake Engineering and Soil Dynamics, pp. 101 106, 1981

24) Conn, G. M. and Hyde, A. F. L. : Critical Level of Repeated Loading for a Silty Clay, Proc. 3rd Canadian Conference on Marine Geotechnical Engineering, Vol. 2, pp. $691 \sim 705,1986$

25) Hyde, A.F.L. and Conn, G. M. : Discussion on 
"Cyclic Triaxial Tests on Remoulded Clays by Procter, D. C. and Khaffaf, J.H., Vol.110, No.10, pp.1431 1445, 1984", Journal of Geotechnical Engineering, ASCE, Vol. 113, No.6, pp. 665 667, 1987

26）日本建築学会：建築基礎構造設計指針, pp. 215 240, 1988

27）村山朔郎, 柴田 徹：粘土中の摩擦グイの支持力とその 新測定法，土木学会論文集，第 59 号, pp. 49 56, 1958

28) Fredriksson, A. and Rosen, R. : Foundation on Creep Piles: Design Parameters, Graphical Presentation by Computer of Resultant Force Systems as well as an
Analysis of Test Pile Results, Proc., 11th ICSMFE, Vol. 3, pp. 1383 1386, 1985

29）杉村義広ほか 6 名：場所打ちコンクリート杭基礎の引抜 き耐力に関する研究 (その 8 . まとめ)一高層壁式ラーメ ン構造に関する研究一, 日本建築学会大会学術講演梗概 集 B構造 I，pp. 1059 1060，1987

30）茶谷文雄：杭の引抜き抵抗について, 日本建築学会大会 学術講演梗概集 B 構造 I, pp. 1317－1318， 1989

（1992 年 6 月 8 日原稿受理, 1992 年 8 月 25 日採用決定） 